\title{
Federally Collected Non-oil Tax Revenue and National Economic Performance in Nigeria: A Pre - post Treasury Single Account Implementation Assessment
}

\author{
Stanley Ogoun, Odogu Terry Keme Zuode \\ Department of Accounting, Management Sciences, Niger Delta University, Wilberforce Island, Bayelsa State, Nigeria \\ Email address: \\ stanleyogoun@ndu.edu.ng (S. Ogoun), stanleyogoun@gmail.com (S. Ogoun), odoguterry@gmail.com (O. T. K. Zuode)
}

To cite this article:

Stanley Ogoun, Odogu Terry Keme Zuode. Federally Collected Non-oil Tax Revenue and National Economic Performance in Nigeria: A Pre - post Treasury Single Account Implementation Assessment. Journal of Finance and Accounting. Vol. 8, No. 4, 2020 , pp. 190-198.

doi: $10.11648 /$ j.jfa.20200804.14

Received: April 26, 2020; Accepted: June 28, 2020; Published: July 13, 2020

\begin{abstract}
This paper examined the implementation of Treasury Single Account (TSA) on federally collected non-oil tax revenue and national economic performance in Nigeria, via an inter-period comparative milieu. This study was stimulated by the divergent opinion amongst stakeholders on the justification and efficacy of the TSA model. The study was underpinned by the stakeholder and public finance management theories. Mulled after the ex post facto research template, before (pre) and after (post) implementation data of the corresponding periods were obtained from the annual bulletins/reports of Federal Inland Revenue Service (FIRS), Central Bank of Nigeria (CBN) and Nigerian Bureau of Statistics (FBS). While, actual reported tax revenue for the corresponding periods were obtained, gross domestic product was deployed to proxy national economic performance. Paired sample t-test was used to process the data on the Statistical Package for Social Sciences (SPSS) template. The results revealed that, in gross terms more revenue was collected pre-TSA. However, a significant increase in federally collected revenue post TSA implementation was achieved, granted that the economy slipped into recession from the third quarter of 2015, also a considerable growth in GDP. In essence, both measures performed better in the post implementation period from a comparative strand. This implies that, the TSA policy has a positive bearing on both non-oil tax revenue generation and economic performance. Following, it is recommended that government should improve on the existing TSA framework by incorporating complementary, supportive control and monitoring measures to perfect the operation of the system, and to escalate the system further towards monitoring outflows (expenditure),
\end{abstract}

Keywords: Treasury Single Account, Non-oil Revenue, Economic Performance, Comparative, Pre-post Period

\section{Introduction}

The pursuit of economic performance resonates around all nations of the globe. Nations at all strata of the economic performance index, continue to pursue strategic objects designated by their various levels of their ranking. The objects of the pursuit range from growth aspirations, for those on the lower and middle strata, to performance sustainability for those considered as developed nations. The implication of this broad-based pursuit, is the deployment of various alternative strategies considered appropriate to each level of engagement. Furthermore, gleaned from the paradigm of experiential learning and adaption, economic performance models have been handed down to those on the lower strings of the economic growth ladder, by the global financial institutions. These have come with strings of policy dynamics, that have been recommended as tell-tale steps to economic growth.

Furthermore, in pursuit of this global and yet individualized national agenda, economic performance foreclosure variables in under-developed and developing nations, have been decomposed in the extant literature to include, corruption, instability in government, institutional weakness, poor economic management etc. The numerous foreclosure variables designated by the extant literature have been accompanied with remediation measures. Following, one of the designated critical causative factors, is the corruption pandemic, as manifested in its ravaging of the economies of most developing countries. Corruption is a 
major disadvantage to development [8]. Corruption and fraud are key critical foreclosure variables as lamented by [32]. Prior studies had demonstrated how the absence of fiscal transparency, on account of corruption, has smeared the developmental aspirations of Nigeria, compromised its public service, as well as decimated the whole gamut of the StateOwned Enterprises sector [27, 28, 22].

Specifically, the manifestation of this corruption pandemic as driven by human greed, was clearly pronounced in the tax administrative structure beyond the domain of public procurement [30]. The harvesting of crude in commercial quantity, and its emergence as the prime revenue earner for the nation, meant the methodological confinement of taxation to the background as deposed by [29]. This is despite taxation's rich historical pedigree, as the prime source of state revenue. This systemic neglect led to a near total collapse of the national tax infrastructure, leaving what was left of it to be exploited by opportune government officials, for individual gain. There was massive fleecing of tax revenue by individuals. As such, taxation lost its prime place as a veritable instrument for harnessing public revenue, from its rich colonial and early post-independence heritage. No doubt, the cascading effect of this ugly methodological decimation of the tax infrastructure, was the emergence of a complex and confused array of taxes, well designated as a regime of multiple taxation. However, with the glut in the international market for crude oil and its attendant implications for cash squeeze, the ruins of the tax system received attention, leading to the era of tax reforms. By the time the abandoned ruins were visited, it was observed that the opportune individuals had bored several holes into the tax cash bag, leading to massive leakages.

Specifically, due to several instances of diversion and embezzlement of non-oil (tax) revenue and the associated effect of low revenue reported by the FIRS, the Federal Government of Nigeria accepted the model of a national banking system called Treasury Single Account (TSA) in 2004 [26, 6, 33, 42]. While, the phased and systematic implementation began in 2012, full implementation commenced in 2015. The TSA system is designed to monitor and control government revenue in order to stifle corruption in Nigeria [5]. The essence of the model was to ensure that all revenue accruing (inflows) to the government where pulled into a single account at the Central Bank, leaving no room for leakages. This was with the intent that funds will be available for the pursuit and attainment of national economic developmental aspirations. The question however is, has the adoption and implementation of TSA significantly improved government revenue from the non-oil sector? Secondly, given its luring objectives, has the TSA policy improved the economic performance (measured in GDP) of Nigeria? The twin objectives of this study are therefore to find out if the TSA banking system has significantly improved government non-oil tax revenue and improved economic performance since its full implementation in August, 2015 interrogated from a comparative milieu.

The relevance of interrogating the TSA construct from our espoused model, is that it has attracted various prior research efforts. Early post-implementation studies in 2016 had addressed part of the first query raised. However, the results have not been conclusive. The implementation of TSA has not improved revenue generation in Nigeria [25]. Contrary to the observation by [25] other earlier post-implementation studies anchored the revenue generating potential of the TSA system $[2,7,45,1]$. Also, similar works did depose that TSA had increased the revenue profile of the government, see [18, $23,3]$. However, one of the basic constraints of these prior studies is that a one-year implementation run, was too short a time to empirically assess and conclude on the effect of the scheme. Furthermore, some were also premised on pure theoretical espousal, lacking in empirical depth and interperiod comparative milieu. In addition, the period 2012 to 2014 was a mixed grill, (as partial implementation had commenced), which should have been isolated, thus distorting the data set used for the analysis. Furthermore, the effect on the economy (measured in GDP) was not espoused in these earlier studies. It is this gap that incentives the current effort and anchors its relevance.

\section{Literature and Hypotheses Development}

\subsection{Overview of the Treasury Single Account Construct}

Treasury Single Account (TSA) is a global financial policy practiced by both developed and developing countries [37]. It is an international monetary and fiscal best practice policy, coordinated and institutionally rooted in Central or National Banks, such as the Central Bank of Nigeria [5]. It was adopted as conceived and proposed to the Federal Government of Nigeria, in order to consolidate all inflows from all Federal Ministries, Departments and Agencies into a "Single Account" at the Central Bank of Nigeria [38].

TSA is a national system of aggregative financial inclusion that incorporates Ministries, Departments and Agencies (MDAs) of the divergent federating units of the country [1]. Furthermore, it is seen as a unified structure of government bank accounts, which consolidates government cash receipts for optimal utilization [36, 47]. In other words, TSA is a network of subsidiary accounts linked to a single account where balances of transactions effected in subsidiary accounts are closed and transferred into a national/federal account [10]. It is also described as a process and tool for effective management of government's finances, banking and cash position [12]. Similarly, TSA is considered as an essential tool that consolidates and manages the cash receipts, and or, resources of government by the Central Bank of the country [17]. TSA is a bank account or a set of linked accounts, through which the Federal Government receives all its revenues and make its payments $[44,14]$. TSA, as it were, is a unifying public accounting system and tool, under which all receipts, and or, revenues are collected into one single account, through a set of linked bank accounts controlled and monitored by the Central Bank. It is thus, an account under which the government makes all its receipts and payments and gets a consolidated view of its cash position at any given time.

Historically, the TSA banking system was conceived to fulfil 
Vision 20: 20: 20 and to address perceived impediments to effective and efficient cash management in Nigeria. It was recommended in 2004 by the Economic Reform and Governance (ERG) Programme, in line with the Public Financial Management (PFM) reforms. Although, the Accountant General of the Federation issued a treasury circular to all MDAs for its take-off on the $1^{\text {st }}$ of January, 2009, the TSA system was fully adopted and partially became operational in 2012 [24]. It got the needed political backing on the $9^{\text {th }}$ of August 2015, when the Federal
Government sternly ordered all MDAs to close their individual bank accounts into the federation account, under the auspices of the Central Bank of Nigeria $[39,41,12,16]$. The TSA policy is therefore a banking system conceived, considered, adopted and implemented by three different Executive Presidents of Nigeria, to increase government revenue and eradicate embezzlement and misappropriation of public fund.

Below is an illustration of a simple revenue generation circuit under the TSA system.

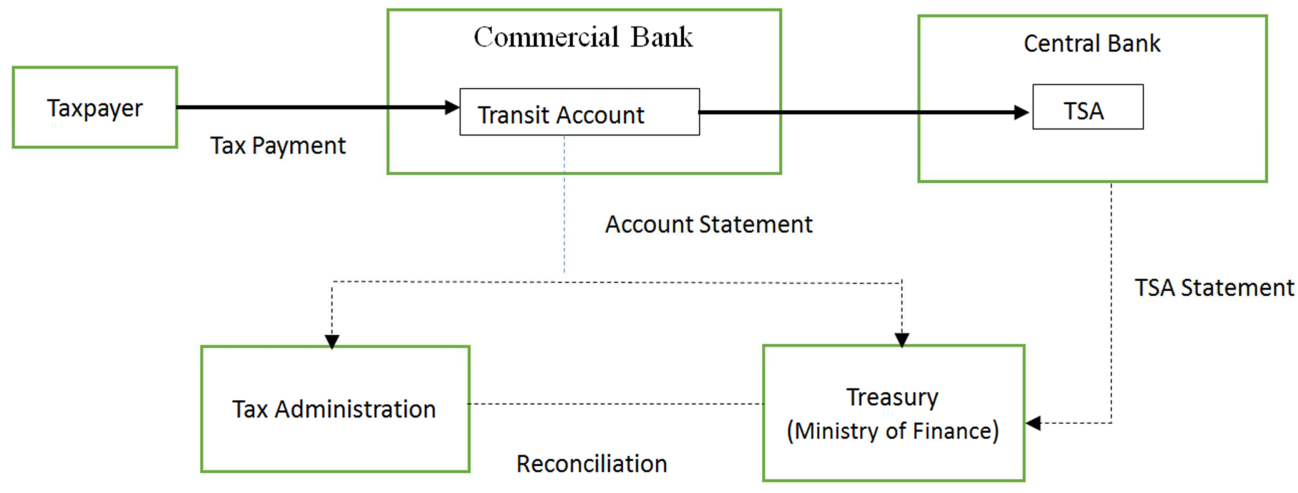

Source: Adopted from Pattanayak \& Fainboim (2010).

Figure 1. A simple Revenue Circuit under TSA.

\subsection{Tax Revenue}

Government generates revenue from many different sources. One of the sources of government revenue is tax [42]. Tax is a compulsory levy imposed by governments of nations on the income (and or profits) of individuals and companies [21].
Taxes in Nigeria are categorised and collected at the Federal, State and Local government levels [43]. Taxes payable to the Federal Government are administered by the Federal Inland Revenue Service (FIRS). Below is a Table showing Taxes collectable by the FIRS in Nigeria:

Table 1. Non-Oil Taxes Collected by FIRS.

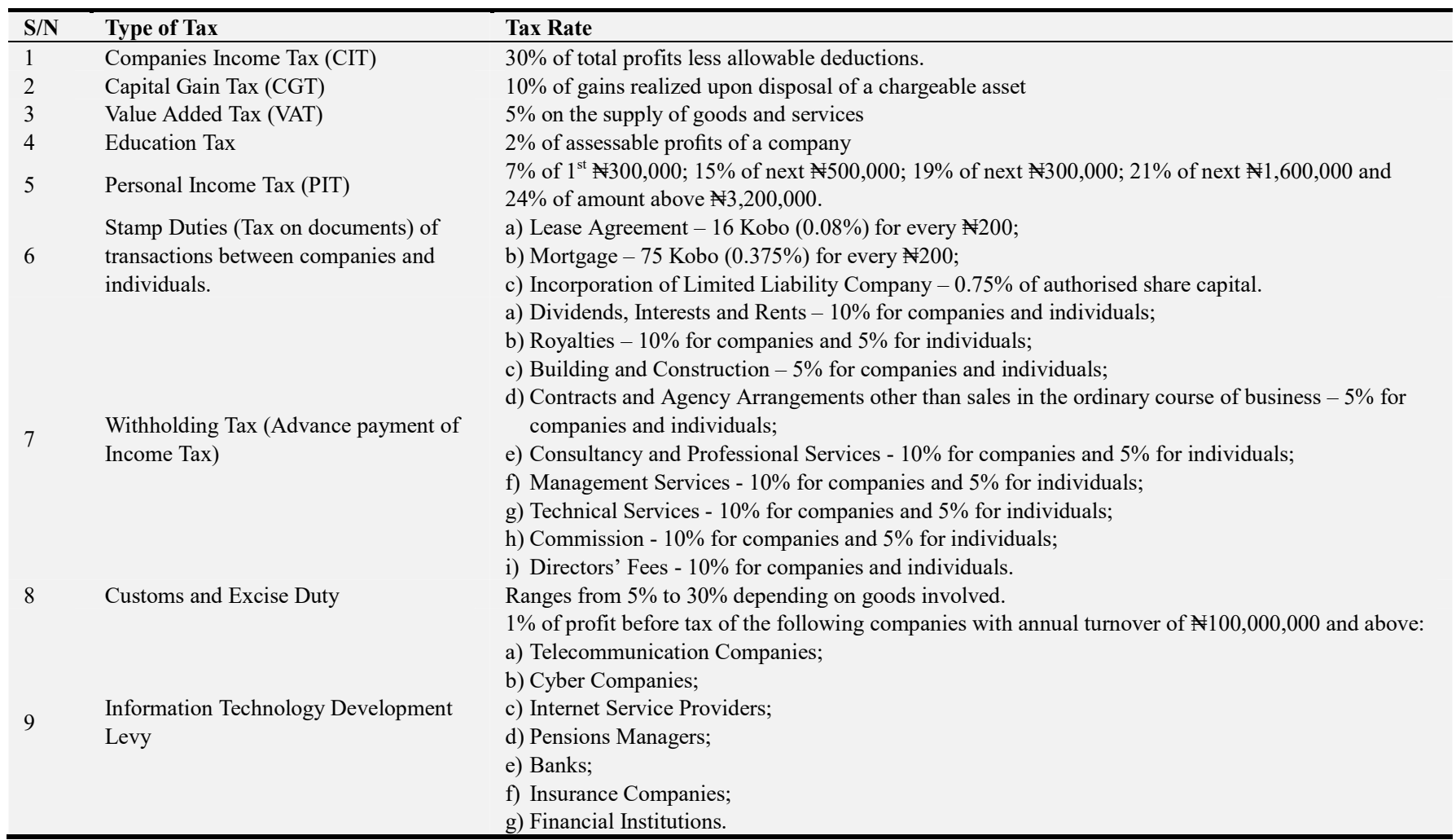

Source: Extracted and Modified from Strachan Partners (2018). 
Federal Government taxes were collected through multiple bank accounts operated by different Ministries, Departments and Agencies (MDAs) in commercial banks before the implementation of TSA in April, 2015 [44]. Government revenues in pre-TSA years were not adequately collected and accounted for, at all levels as observed by [11]. The operation of multiple bank accounts for the administration of government revenues by MDAs in the pre-TSA era, contravened the Constitution of the Federal Republic of Nigeria [44]. Sections 80 and 162 of the 1999 Constitution of the Federal Republic of Nigeria directs all federally-collected revenues to be paid into the Federation Account $[5,15]$. The modus operandi before the TSA implementation era was indeed, a flagrant breach of the Constitution of Nigeria [44]. Thus, the adoption and eventual implementation of TSA is not only for financial efficiency but a constitutional requirement. However, the question is, how far has Nigeria reaped the purported benefits of TSA? Hence:

$\mathrm{Ho}_{1}$ : TSA has no positive significant effect on federally collected non-oil tax revenue in Nigeria.

\subsection{Theoretical Framework}

This study is underpinned by two theories based on the various questions, stakeholders ask about the justification and efficacy of TSA, and the purported objectives of TSA. These theories are briefly discussed below:

a) Stakeholder Theory

This theory was propounded by Freeman in 1984, who argued that organisations (like the government) have a variety of stakeholders (such as investors/shareholders, employees, customers, suppliers, creditors, local community, etc.) to satisfy. Thus, the average stakeholder wants managers (agents) of organisations (or the government) to be efficient and transparent in the realization, appropriation and management of resources. The assumption is that, the adoption and implementation of TSA is as a result of the yearnings, demands and pressure on government by critical stakeholders to eradicate corruption, embezzlement and mismanagement in the realization, appropriation and management of government revenue. Against this backdrop, the stakeholder's theory can be said to be the motivating factor for the adoption and implementation of the TSA system by the Federal Government of Nigeria [25].

b) Public Finance Management Theory

This theory advocates for prudence in the management of public funds. It argues that government revenues should be well mobilized and appropriately appropriated to avoid looting and misapplication of funds [7, 25]. It calls for efficient management and prioritization of resources and programmes in the budgetary process. This, of course, is the concern of stakeholders and the general public, and is in tangent with the objective of the TSA. This theory therefore, suggests the adoption of the TSA where all transactions between the government and the non-governmental sector (private individuals, commercial banks and the external/foreign sector) are made through a single (government treasury) account controlled and regulated by the Apex (Central) Bank [13].

\subsection{Further Empirical Premise}

The TSA approach is a new system of banking by the (federal) government of Nigeria. It has attracted great academic and research attention right from its conception, adoption and implementation to date. Before its adoption, it was recommended for countries that have fragmented government banking arrangements [37]. Consequently, the TSA model was decomposed and observed as that which would enhance proper cash management and reconcile revenue collection and payment by [2]. In examining the effects of TSA on public finance management in Nigeria [7], reported that TSA can block financial leakages, as well as, promote transparency and accountability in the Nigerian public financial system. In another study on the adoption, benefits, challenges and prospects of TSA by State Governments of Nigeria [45], observed that the adoption and full implementation of TSA would greatly benefit State Governments and the Nigerian nation at large. A complementary study by [1], observed that TSA is an efficient and effective tool that provides and enforces sufficient self-control mechanism on revenue generation and budget implementation. Similar conclusion was also arrived at by the work of [18], who opined in that TSA was introduced in Nigeria due to numerous corrupt practices and lack of transparency and accountability. More so, TSA was introduced to reduce the proliferation of bank accounts operated by Federal MDAs in Nigeria, as adduced in the work of [23]. Interestingly, [46] in his book (Implementation of TSA and Nigerian Economy) vouched that TSA would improve revenue generation in Nigeria.

Empirical findings on TSA from studies done in 2017 and 2018 are controversial, unlike earlier findings in pre and early post TSA implementation years. For instance, from a theoretical perspective, TSA was seen as designed to properly monitor Federal Government receipts and expenditure in Nigeria [34]. Also, a three-year post-TSA implementation study on "the effect of TSA on some selected Federal Parastatals in Kano State", found that it has blocked all financial leakages and promoted transparency in the parastatals [44]. Consequently, he concluded that TSA has significantly reduced corruption in Federal Parastatals in Kano State. However, the assertion by [3] is quite different and challenging. They did a study on TSA and government revenue in Nigeria, and concluded that the TSA policy has increasingly supported government revenue collection and remittance, but is yet to safeguard close monitoring of government expenditure in Nigeria. This question the success of TSA implementation in Nigeria, but is in tangent with the arguments of other scholars in the area of revenue generation, which of course, is the concern of this study. In a contrary deposition, [25] categorically stated that the implementation of TSA has not improved revenue generation in Nigeria. This justifies the rhetoric questions stakeholders ask on the 
benefits and success of the TSA system since its implementation in 2015, which gives further impetus to this study.

The majority of the literature supports the increase in nonoil tax revenue. However, the reality is that government does not accumulate revenue as an end, but as a means to an end. This necessitates the enquiry as to whether the improved revenue profile correspondence economic performance, from a corresponding inter-period analytical milieu, as espoused in this study. This collates the espoused second hypothesis of this work capture herein:

$\mathrm{Ho}_{2}$ : TSA implementation has no positive significant effect on the economic performance of Nigeria within the mulled period as discriminated by GDP.

\section{Methodology}

This is a quantitative study that used secondary data on non-oil (tax) revenue between 2008 to 2011 and 2015 to 2018, from FIRS, CBN and NBS Annual Publications (Bulletins). Specifically, data used are only annual non-oil (tax) revenues generated and reported by the Planning, Reporting and Statistics Departments of FIRS of Nigeria, from 2008 to 2011 (being four years total non-oil tax revenue generated before the implementation of TSA), and from 2015 to 2018 (being four years total non-oil tax revenue generated after the implementation of TSA). This is because TSA was introduced and partially implemented in 2012 until it was fully adopted and implemented by all MDAs in Nigeria in 2015. Consequently, a comparative study and analysis of the performance of TSA using pre-adoption and post-adoption statistics logically excludes the years (2012, 2013 and 2014) as it was partially implemented (representing a mixed grill). However, reference was made to this three-year period of partial implementation, as a kind of control period, to further verify the findings of [31] and [25], using four years figures, beginning from a pre-adoption year (2011). The inclusion of 2011 was to maintain a corresponding (unbroken) four years partial-adoption (paired) period with the four years postadoption period.

It adopted a pre-post (difference in mean) operationalised through the ex post facto research design, which entails taking measurements before and after a treatment (e.g. TSA implementation). This was to measure the effect of TSA on Federal Government non-oil (tax) revenue and economic performance (comparing pre-TSA implementation figures and post-TSA implementation figures). On this note, paired sample t-test was used as the data analysis technique with the help of SPSS 22. Since paired sample t-test is a statistical procedure used to determine whether the mean difference between two sets of observations is zero [25]. This required the grouping of each data into two observations: Pre-TSA implementation period and PostTSA implementation period. This justifies the appropriateness of the name of the research design (PrePost) and the method employed.

\section{Data Analysis and Test Outputs}

\subsection{Data Analysis}

Time series data on non-oil (tax) revenue collected by the FIRS were obtained from the FIRS, CBN, NBS Bulletins/Reports and National Dailies, on annual basis from 2008 to 2011 and 2015 to 2018 , resulting to a total of 8 observations. The data were divided into two periods: Pre-TSA era (period before the implementation of TSA 2008 to 2011 and Post-TSA era (period after the full implementation of TSA - 2015 to 2018). This is shown in Table 2 below:

Table 2. Annual Non - Oil (Tax) Revenue for the Periods.

\begin{tabular}{lll}
\hline Periods (Years) & Federal Tax ( & GDP ( \\
\hline Pre -TSA Implementation Era & & \\
2008 & 2.97 trillion & 39.95 trillion \\
2009 & 2.20 trillion & 43.46 trillion \\
2010 & 2.84 trillion & 54.61 trillion \\
2011 & 4.63 trillion & 63.14 trillion \\
Post -TSA Implementation Era & & \\
2015 & 3.08 trillion & 94.14 trillion \\
2016 & 3.30 trillion & 101.49 trillion \\
2017 & 4.03 trillion & 113.71 trillion \\
2018 & 5.32 trillion & 127.76 trillion \\
\hline
\end{tabular}

Source: FIRS (2014); CBN Annual Report (2015); CBN \& National Bureau of Statistics Bulletin (2018); Premium Times (2019); Punch (2019).

Table 2 above shows 8 years' Federally Collected Tax (FCT) and Gross Domestic Product (GDP) figures before (Pre) and after (Post) the implementation of TSA in Nigeria. The mean values for the two periods (Pre-TSA and PostTSA) were sought for and compared for analysis, using SPSS 22. To achieve this:

1. Total Federally Collected Tax before (Pre) TSA implementation period is represented by $\mathrm{FCT}_{1}$;

2. Total Federally Collected Tax after (Post) TSA implementation period is represented by $\mathrm{FCT}_{2}$;

3. Gross Domestic Product before (Pre) TSA implementation period is represented by $\mathrm{GDP}_{1}$, and

4. Gross Domestic Product after (Post) TSA implementation period is represented by $\mathrm{GDP}_{2}$

This is shown in Table 3 below:

Table 3. Paired Samples Statistics.

\begin{tabular}{llllll}
\hline & & Mean & N & $\begin{array}{l}\text { Std. } \\
\text { Deviation }\end{array}$ & $\begin{array}{l}\text { Std. Error } \\
\text { Mean }\end{array}$ \\
\hline \multirow{2}{*}{ Pair 1 } & $\mathrm{FCT}_{1}$ & 3.1600 & 4 & 1.03618 & 0.51809 \\
& $\mathrm{FCT}_{2}$ & 3.9325 & 4 & 1.01019 & 0.50510 \\
\multirow{2}{*}{ Pair 2 } & $\mathrm{GDP}_{1}$ & 50.2900 & 4 & 10.60424 & 5.30212 \\
& $\mathrm{GDP}_{2}$ & 109.2750 & 4 & 14.73136 & 7.36568 \\
\hline
\end{tabular}

Source: Computational out

From table 3 above, federally collected tax before the implementation of TSA $\left(\mathrm{FCT}_{1}\right)$ has a mean (monetary) value of $\$ 3.1600$ trillion with a standard deviation of 1.03618 trillion. On the other hand, federally collected tax after the implementation of TSA $\left(\mathrm{FCT}_{2}\right)$ has a mean (monetary) value of $\$ 3.933$ trillion with a standard 
deviation of 1.010 trillion. The above statistics further reveals that, four years' average gross domestic product of Nigeria before the implementation of TSA $\left(\mathrm{GDP}_{1}\right)$ was $\$ 50.2900$ trillion and that the standard deviation of the gross domestic product for period was 10.60424 trillion. The result in table 3 also indicates that Nigerian gross domestic product for four years after the implementation of TSA $\left(\mathrm{GDP}_{2}\right)$ was statistically 109.275 trillion, with a standard deviation of 14.731 trillion. The above indices imply that the FIRS generated more revenue from tax before the implementation of TSA in Nigeria. Unarguably, $\$ 4.790$ trillion $\left(\mathrm{FCT}_{1}\right.$ mean) $>33.933$ trillion $\left(\mathrm{FCT}_{2}\right.$ mean). However, despite the fall in tax revenue in the post TSA $\left(\mathrm{FCT}_{2}\right)$ period, the national gross domestic product $\left(\mathrm{GDP}_{2}\right)$ increased from $\$ 75.955$ trillion (Pre-TSA period) to 109.275 trillion (Post-TSA period). This is confirmed by the Paired Samples Correlation result below:
Table 4. Paired Samples Correlation.

\begin{tabular}{lllll}
\hline & & N & Correlation & Sig. \\
\hline Pair 1 & $\mathrm{FCT}_{2} \& \mathrm{FCT}_{1}$ & 4 & 0.885 & 0.115 \\
Pair 2 & $\mathrm{GDP}_{2} \& \mathrm{GDP}_{1}$ & 4 & 0.995 & 0.005 \\
\hline
\end{tabular}

Source: Computational out

Table 4 above reveals that the relationship between the two tax periods $\left(\mathrm{FCT}_{2} \& \mathrm{FCT}_{1}: 0.885\right)$ relative to the TSA policy is positive, which implies a rise in tax revenue in the post-TSA period (as earlier indicated by the paired samples statistics result: $3.9325 \mathrm{FCT}_{2}>3.1600 \mathrm{FCT}_{1}$ ). On the other hand, the relationship between the two economic periods $\left(\mathrm{GDP}_{2} \& \mathrm{GDP}_{1}\right.$ : $0.995)$ relative to the TSA policy is also positive. This signifies a significant growth in GDP and is consistent with the paired samples statistics result in Table 4: $109.2750 \mathrm{GDP}_{2}>50.2900$ $\mathrm{GDP}_{1}$ ). The above results, analyses and interpretations can be further tested using Paired Samples Test:

\section{2. t-Test Output}

Table 5. Paired Samples t-Test.

\begin{tabular}{lllllll}
\hline & & \multicolumn{2}{c}{ Paired Differences } & \multicolumn{2}{c}{ Sig. (2 tailed) } \\
\cline { 3 - 5 } & & Mean & Std. Deviation & Std. Error Mean & & \\
\hline Pair 1 & $\mathrm{FCT}_{2}-\mathrm{FCT}_{1}$ & 0.77250 & 0.49237 & 0.24688 & -3.138 & 3 \\
Pair 2 & $\mathrm{GDP}_{2}-\mathrm{GDP}_{1}$ & -58.98500 & 4.30776 & 2.15388 & -27.385 & 3 \\
\hline
\end{tabular}

Source: Computational out

The Paired Samples test in table 5 above shows that federally collected tax has a positive mean difference of $\$ 0.773$ trillion. This implies that the implementation of TSA has a positive effect on federally collected tax revenue in the Post-TSA $\left(\mathrm{FCT}_{2}\right)$ period. Quantitatively, $\mathrm{t}(3)=-3.138, \mathrm{SD}=$ 0.49237 and $\mathrm{p}=$ approximately 0.05 . On the other hand, gross domestic product also has a positive mean difference of - 558.985 trillion. This implies that the implementation of TSA has a positive and significant effect on the economy of Nigeria in the Post-TSA $\left(\mathrm{GDP}_{2}\right)$ period. Econometrically, $t$ $(3)=-27.385, \mathrm{SD}=4.30775$ and $\mathrm{p}=0.000$

Succinctly, the analysis and interpretations of the outcomes of the different tests conducted disclosed that the implementation of treasury single account improved tax revenue generation in Nigeria. Drawn from the implicit decision rule for testing hypotheses, the first null hypothesis $\left(\mathrm{Ho}_{1}\right)$ of this study did not pan out and is therefore rejected. Also, the second hypothesis did not pan out as indicated by the test output, implying that the implementation of TSA bears significantly on the economic performance of the nation within the period under review.

As early stated, a comparative analysis and discussion of the partial-TSA implementation period $(2011-2014)$ and the full-TSA implementation period (2015-2018) is done below from a summarised table of selected analytical indices used in the preceding tables:

Table 6. Summary of Part-TSA implementation and full-TSA implementation figures (indices).

\begin{tabular}{|c|c|c|c|c|c|c|c|}
\hline & TAX N-Trillion & $\begin{array}{l}\text { GDP N } \\
\text { Trillion }\end{array}$ & $\begin{array}{l}\text { Paired S- } \\
\text { Stat Mean }\end{array}$ & $\begin{array}{l}\text { Paired S- } \\
\text { Stat Std Dev }\end{array}$ & $\begin{array}{l}\text { Paired Sample } \\
\text { Correl }\end{array}$ & $\begin{array}{l}\text { Paired } \\
\text { Diff Mean }\end{array}$ & $\begin{array}{l}\text { Paired Diff } \\
\text { Sig (2-t) }\end{array}$ \\
\hline A Total Partial-TSA (2011-1015) figures. & 19.16 & 303.82 & - & - & - & - & - \\
\hline Total Post-TSA (2011-1015) figures. & 15.73 & 437.10 & - & - & - & - & - \\
\hline B Pair Partial FCT & - & - & 4.790 & 0.16411 & - & & \\
\hline Pair Full FCT & - & - & 3.933 & 1.01019 & - & - & - \\
\hline C Pair Partial GDP & - & - & 75.955 & 11.1756 & - & - & - \\
\hline Pair Full GDP & - & - & 109.275 & 14.7313 & - & - & - \\
\hline Pair Full GDP \& Pair Partial GDP & - & - & - & & 0.991 & - & - \\
\hline E Pair Full FCT - Pair Partial FCT & - & - & - & & - & -0.858 & 0.204 \\
\hline Pair Full GDP - Pair Partial GDP & - & - & - & & - & 33.320 & 0.000 \\
\hline
\end{tabular}

Source: Computational out

Succinctly, table 6 above reveals that total federally collected tax revenue in the partial-TSA implementation period was 19.160 trillion with a mean (monetary) value and standard deviation of $\$ 4.790$ trillion and $¥ 0.164$ trillion. Surprisingly, these are greater than the full-TSA implementation figures of $\$ 15.730$ trillion, 3.933 and 
\#1.010 trillion for total tax revenue, mean monetary value and standard deviation, and are contrary to the first (actual) results and findings of this study, but consistent with the findings of $[31,25]$. Furthermore, the relationship between the partial-TSA and full-TSA periods relative to the TSA policy (as shown by the correlation result -225) is negative, which again implies a fall in tax revenue. Also, the paired samples test shows a mean difference of 0.858 trillion, and a $p$ value of $0.204(>0.05)$. This implies a fall in tax revenue and acceptance of the null hypothesis of this study (as it would have been). This fall in tax revenue in the full-TSA implementation period can be hypothetically related to recessionary experience of low economic/business activities, low investment inflows, corporate failures and increased unemployment in the country, as earlier observed by [19, 4]. This is a potential gap for further study.

On the other hand, total GDP in the partial-TSA implementation period was $\$ 303.820$ trillion with a mean (monetary) value and standard deviation of $\$ 75.955$ trillion and 11.175 trillion, which are less than the full-TSA implementation figures of $\$ 37.100$ trillion total GDP, N109.275 trillion mean monetary value and 14.731 trillion standard deviation. This is in agreement with the first and actual results and findings of this study, and the research findings of [19, 4, 25].

Moreover, the relationship between the two economic periods of partial-TSA and full-TSA implementation (as shown by the correlation result 0.991 ) is positive, which signifies a growth in GDP and fall in tax revenue. Furthermore, the paired samples test reveals a mean difference of $\$ 33.320$ trillion, and a $p$ value of $0.000(<0.05)$. This also implies a significant growth in GDP and a rejection of the null hypothesis of this study (as it would have been). However, this increase in GDP, despite the decrease in federally collected tax in the full-TSA (recessionary) period is surprising. Therefore, a further investigation is needed to unveil the causative variables behind it.

\section{Conclusion and Recommendations}

This study is designed to ascertain the effect of the TSA policy implementation on non-oil tax revenue generation and economic performance. This was stylized via a comparative analytical milieu of pre and post implementation corresponding years of the TSA policy. The empirical outcome is indicative of TSA's influence on increased non-oil tax revenue growth, with significant economic performance for the underlying period. Contingent on the foregoing, it is concluded that the TSA banking system has considerably harnessed government non-oil tax revenue, and improved the economic performance of Nigeria. Although, in gross terms, there was a decline in the amount collected in the post implementation period, which was due to the economy slipping into recession from the third quarter of $2015[19,4]$.

Following, the study recommends that the Federal Government of Nigeria should; improve on the existing TSA framework by incorporating complementary and supportive control and monitoring measures and strategies to perfect the operation of the TSA banking system, and to escalate the system further towards monitoring outflow (expenditure), such that the increased inflow is chanelled into improved governance and further enhanced public financial management of the national treasury.

\section{References}

[1] Adebisi, J. F \& Okike, B. M. (2016). The adoption of the Treasury Single Account (TSA) and its effect on revenue leakages of Nigerian states. American Research Journal of Business and Management, 2, 1-10.

[2] Adeolu, I. A. (2015). Understanding the Treasury Single Account (TSA) system - things you should know. Business and Economy, Market Development. John Archers Publishers, Nigeria.

[3] Adetula, D., Adegbenjo, S., Owolabi, F., Achugamonu, U. \& Ojeka, S. (2017). Treasury Single Account and government revenue in Nigeria. Journal of Internet Banking and Commerce, 22, 8, Retrieved from: http://www.icommercecentral.com/open-access/treasurysingle-account-policy-and-government-revenue-innigeria.php?aid $=8600$.

[4] Adeniran, A. O. \& Sidiq, B. O. (2018). Economic recession and the way-out: Nigeria as case study. Global Journal of Human-Social Science, 18, 1, 1-6.

[5] Ahmed-Gamgum, A. W. \& Ahmed, R. W. (2018). The bases and challenges of Treasury Single Account (TSA) in Nigeria. International Journal of Social Sciences and Management Research, 4, 1, 1-11.

[6] Ajaz, T. \& Ahmad, E. (2010). The effect of corruption and governance on tax revenues. The Pakistan Development Review, 49, 4, 405 -417.

[7] Bashir, T. M. (2016). Effects of Treasury Single Account on public finance management in Nigeria. Research Journal of Finance and Accounting, 7, 6, 164-166.

[8] Bologna J 2016 The effect of informal employment and corruption on income levels in Brazil. J. Comp. Econ, 44, 657-695.

[9] Central Bank of Nigeria (CBN) Annual Report and Statements of Accounts (2015). Retrieved from: https://www.cbn.gov.ng/Documents/cbnannualreports.asp

[10] Chukwu, O. (2015). Banks face liquidity strain as FG fully enforces treasury single account. This Day Newspaper, Monday 11 August, 52.

[11] Ekubiat, J. U. Ime, E. E. (2016). Adoption of Treasury Single Account (TSA) by State Governments of Nigeria: benefits, challenges and prospects. Journal of Finance and Accounting, 4, 126- 130

[12] Eme, O. I \& Chukwurah, D. C. (2015). An analysis of the pros and cons of the Treasury Single Account Policy in Nigeria. Arabian Journal of Business and Management Review, 5, 4, 20-40.

[13] Eric, T. \& Wray, L. R. (2013). Modern money theory 101: A reply to critics. Levy Economics Institute of Bard College, Working Paper No. 778. 
[14] Fatile, J. O. \& Adejuwon, K. D. (2017). The implication of treasury single account (TSA) on cost of governance in Nigeria: Buhari civilian administration in perspective. International Journal of Advanced Studies in Economics and Public and Public Sector Management, 5, 2, 13-29.

[15] Federal Government of Nigeria (1999). The Constitution of the Federal Republic of Nigeria 1999 (as Amended).

[16] Ganyam, A. (2018). Effect of Treasury Single Account (TSA) on financial accountability, corruption and financial discipline in the Nigerian public sector. Retrieved from: https://www.researchgate.net/publication/326986103_Effect of Treasury_Single_Account TSA_on Financial_Accountabi lity_Corruption_and_Financial_Discipline_in_the_Nigerian Public Sector

[17] Isa, A. A. (2016). Treasury single account as an instrument of financial prudence and management: Prospects and problems. Research Journal of Finance and Accounting, 7, 4, 66-70.

[18] Kanu, C. (2016). Impact of treasury single account on liquidity. Abc Journal of Advanced Research, 5, 1, 43-51.

[19] Mailafia. D. I. (2016). The Structural Economic Dimensions of Unemployment: Associated Factors and Imperatives for Sustainable Development in Nigeria. Being Inaugural Lecture, University of Jos.

[20] Mba P. I. (2015) Treasury Single Account (in Nigeria) Issues and Implications. A Seminar Paper Presented at Covenant University, Ota Nigeria. Retrieved from: covenantuniversity.edu. ng/content/download/41643/282581.

[21] Neumark, F., McLure, C. E. \& Cox, M. S. (n.d). Taxation. Retrieved from: https://www.britannica.com/topic/taxation.

[22] Obara C. L. and Ogoun S. (2014). Fiscal Transparency and Corporate Collapse: A Post Mortem Analysis of State-Owned Enterprises in Nigeria. Research Journal of Finance \& Accounting, Vol. 5, No 18.

[23] Odewole, P. O. (2016). Treasury single account: A tool for effective cash management in Nigeria. Journal of Finance and Accounting, 4, 6, 2016, 328-335.

[24] Odia, J. O. \& Odia, A. A. (2016). E-government and corruption in Nigeria: The case of Treasury Single Account (TSA). Afro Asian Journal of Social Sciences, 7, 4, 1-25.

[25] Offurum, C. N., Oyibo, P. C. \& Ahuche, Q. E. (2018). Impact of treasury single account on government revenue and economic growth in Nigeria. International Journal of Academic Research in Business and Social Sciences, 8, 5, 283-292.

[26] Ogbonna G. N. (2009) Burning Issues and Challenges of the Nigerian Tax Systems with Analytical Emphasis on Petroleum Profits Tax. International Academy of Business and Behavioral Sciences, USA, 1, 1, 80-100.

[27] Ogoun, S. and Ogoun B. (2012). Fiscal Transparency and National Development: A Theoretical Exposition of a Nigerian Imperative. International Journal of Innovative Research and Development, Vol. 1 Issue 11. www.ijird.com

[28] Ogoun, S. and Owota, G. (2013). Institutional Control Measures, Fiscal Transparency and Accountability in Nigeria: A Public Service Behaviour Modification Assessment. International Journal of Innovative Research and
Development, May, 2013, Vol. 2 Issue 5. www.ijird.com

[29] Ogoun, S. (2014). Effective Tax Administration and Institutionalization of Accounting Systems in Small and Medium Scale Enterprises. Journal of Empirical Studies Vol. 1 , Issue 2 .

[30] Ogoun S. (2020). Government has no business being in business: Evidence to the contrary. The International Journal of Business and Management, Vol. 8, issue 2.

[31] Oguntodu, J. A., Alalade, Y. S. A., Adekunle, Y. A. \& Adegbie, F. F. (2016). Treasury Single Account and Nigeria's Economy Between 1999 and 2015: An Assessment. Journal of Accounting and Financial Management. 2, 6, 61-75.

[32] Ojiakor, I. P., Anisiuba, C. A. \& Nnam, I. J. (2017). Appraisal of the activities of anti-graft agencies towards curbing corruption and financial crimes in Nigeria. Journal of Advanced Management and Social Sciences, 4, 3, $196-216$.

[33] Okauru, I. O. (2012). Federal Inland Revenue Service and Taxation Reforms in Democratic Nigeria. Oxford: African Books Collective.

[34] Okerekeoti, C. U. \& Okoye, E. I. (2017). Treasury Single Account in Nigeria: A Theoretical Perspective. A Conference Paper presented at Faculty of Management Sciences International Conference on African Entrepreneurship and Innovation for Sustainable Development, At Nnamdi Azikiwe University, Awka, Nigeria.

[35] Onyekpere, E. (2015). TSA will prevent leakages in generation, management of revenue. Retrieved from: http:/guardian.ng/sunday-magazine/treasury-singleaccountgiving-life-to-jonathans- dead-policy-directives/

[36] Onyekpere, L. (2015). Buhari orders federal ministries, agencies to open Treasury Single Account. The Punch Newspaper, August 9.

[37] Pattanayak, S. \& Fainboim, I. (2010). Treasury Single Account: Concept, Design and Implementation Issues. IMF Working Paper 10/143, Retrieved from: http://www.imf.org/ external/pubs/cat/ longres.cfm?sk=23927.0.

[38] Premium Times (2012). 15 Things to know about Treasury Single Account (TSA)". Retrieved from: $\mathrm{http}: / /$.www.premiumtimesng.com/features-and-unknowntreasury-single-account- $\mathrm{html}$.

[39] Premium Times (2015). Buhari orders Federal Ministries, Agencies to open Treasury Single Account. Retrieved from: http://.www.premiumtimesng.com/news/headlines/188074buhari-orders-federal-ministries-agencies-to-open-treasurysingle-account-html

[40] Premium Times (2019). FIRS recorded N4 trillion tax revenue collection in 2017- Fowler. Monday, August 12.

[41] Punch (2019). FIRS Makes N5. 32 trillion in 2018, targets N8. 3 trillion in 2019. January 2.

[42] Simeon, E. D., Simeon, E. I. \& Robert, I. A. (2017). Issues and challenges inherent in the Nigerian tax system. American Journal of Management Science and Engineering, 2, 4, 52-57.

[43] Strachan Partners (2018). Administration of Income Tax in Nigeria. Retrieved from: http://www.mondaq.com/Nigeria/x/755646/Capital+Gains+Ta $\mathrm{x} /$ Administration $+\mathrm{Of}+$ Taxes $+\mathrm{In}+$ Nigeria . 
[44] Sulaimon, B. A. (2017). Effect of treasury Single Account (TSA) on some selected federal parastatals in Kano metropolis Seminar paper presented at the department of Accounting, Bayero University, Kano, Retrieved from: https://www.academia.edu/31535624/effect-oftreasury-singleaccount-of-some-selected-federal- parastatals-in-Kano.

[45] Udo J. E. \& Esera I. E. (2016). Adoption of treasury single account (TSA) by state governments of Nigeria: Benefits, challenges and prospects. Journal of Finance and Accounting, $4,3,126-130$.

[46] Udoma, U. (2015): Implementation of TSA and Nigerian Economy. Unpublished Paper by Chairman National Planning Commission. Nigeria.

[47] Yusuf, I. A \& Chiejina, N. (2015). Anti-graft war: One economy, one account. Sunday Nation Newspaper, August 16, $9-10$. 